Forcada N., Macarulla M., Fuertes A., Casals M., Gangolells M., Roca X. (2012). Influence of building type on post-handover defects in housing. Journal of Performance of Constructed Facilities, 2012, 26(4):433-440. <doi: 10.1061/(ASCE)CF.1943-5509.0000225>

Final version available at: 〈http://ascelibrary.org/doi/10.1061/\%28ASCE\%29CF.1943-5509.0000225>

\title{
Influence of building type on post-handover defects in housing
}

Nuria Forcada ${ }^{1}$, Marcel Macarulla ${ }^{2}$, Alba Fuertes ${ }^{3}$, Miquel Casals ${ }^{4}$, Marta Gangolells ${ }^{5}$ and Xavier Roca ${ }^{6}$

\footnotetext{
${ }^{1}$ Assistant Professor, Dept. of Construction Engineering, Univ. Politècnica de Catalunya, Group of Construction Research and Innovation (GRIC), C/Colom, 11. Ed. TR5, Terrassa, 08222 Barcelona, Spain (corresponding author). E-mail: nuria.forcada@upc.edu

${ }^{2}$ Researcher, Dept. of Construction Engineering, Univ. Politècnica de Catalunya, Group of Construction Research and Innovation (GRIC), C/Colom, 11. Ed. TR5, Terrassa, 08222 Barcelona, Spain. E-mail: marcel.macarulla@upc.edu

${ }^{3}$ Researcher, Dept. of Construction Engineering, Univ. Politècnica de Catalunya, Group of Construction Research and Innovation (GRIC), C/Colom, 11. Ed. TR5, Terrassa, 08222 Barcelona, Spain. E-mail: alba.fuertes@upc.edu

${ }^{4}$ Assistant Professor, Dept. of Construction Engineering, Univ. Politècnica de Catalunya, Group of Construction Research and Innovation (GRIC), C/Colom, 11. Ed. TR5, Terrassa, 08222 Barcelona, Spain. E-mail: $\underline{\text { miquel.casals@upc.edu }}$

${ }^{5}$ Assistant Professor, Dept. of Construction Engineering, Univ. Politècnica de Catalunya, Group of Construction Research and Innovation (GRIC), C/Colom, 11. Ed. TR5, Terrassa, 08222 Barcelona, Spain. E-mail: marta.gangolells@upc.edu

${ }^{6}$ Assistant Professor, Dept. of Construction Engineering, Univ. Politècnica de Catalunya, Group of Construction Research and Innovation (GRIC), C/Colom, 11. Ed. TR5, Terrassa, 08222 Barcelona, Spain. E-mail: xavier.roca@upc.edu
}

\begin{abstract}
Clients' lack of involvement in defining quality requirements for dwellings built by developers leads to a perception of poor quality at the time of purchase. The research presented in this paper aims to broaden previous research on defects by analyzing the defects that remain in the post-handover stage, which usually lasts 12 months after the handover period, and identifying the factors that influence the appearance of these defects, determining whether a significant difference exists in the quality of the two main residential building types built by developers: flats and detached houses. It also analyzes and discusses the areas and elements in which the defects were detected. The data were obtained from client complaint forms completed after the handover of 95 dwellings in Spain. The data were then statistically analyzed using a t-test analysis, a
\end{abstract}


Pearson's parametric correlation, and a chi-square test. The research reveals that clients detect more defects in flats than in detached houses. The lower quality of the materials used in flats and the tighter schedule to which flats are subject may cause these differences.

CE Database subject headings:

Quality control; Defects; Housing; Spain.

Author keywords:

Quality control; Defects; Housing; Spain.

\section{INTRODUCTION}

Traditionally, most housing has been procured by owner-builders who buy the land and build their own houses. As novices in the business, owner-builders are prone to a number of pitfalls and common mistakes, such as overbuilding for the neighbourhood, liability exposure or a lack of subcontractor management skills. Moreover, the cost of building a single dwelling is much more than the per-home cost of building a group of dwellings, and, as the economy worsens, owners are finding it increasingly difficult to obtain financing to build their own houses. As a result, recent years have seen an increase in dwellings built by developers, who build flats and detached houses for sale upon completion (Asociación de empresas constructoras de ámbito nacional (SEOPAN) 2009). Developers are able to obtain attractive financial packages and improve efficiency and efficacy in terms of time and cost. Typically, they purchase a tract of land, determine how to market the property, draw up the building plan and design, obtain the necessary permits and financing, build the structure, and lease, manage and ultimately sell it.

The housing construction boom of the late 1990s and the first decade of the $21^{\text {st }}$ century, along with the ease of entering the market, led to an influx of inexperienced workers and an increase in competition within the industry. This, in turn, gave rise to a perceived decline in quality. Moreover, the marginal role played by end users in defining functional and quality requirements has fostered a perception of poor quality at the time of purchase. This lack of quality is perceived in the form of defects.

The causes of housing defects are well documented in the published literature (Porteous 1992; Karim, Marosszeky \& Davis 2006; Farrington 1987; Love \& Sohal 2003; Josephson 1998; Hall \& Tomkins 2001; Josephson, Larsson \& Li 2002). This paper aims to broaden previous research on defects by analysing the defects that remain in the post-handover stage and identifying the factors that influence the appearance of these defects, determining whether a significant difference exists in the quality of the two main residential building types built by developers: flats and detached houses.

Most of the research on housing defects has been based on observation and surveys. The research presented in this paper is based on data derived from post-handover client 
complaint forms. The information contained in these forms made it possible to determine the dwelling type, dwelling characteristics, number of defects, area where the defects were observed and defective element.

\section{HOUSING CHARACTERISTICS}

There are several ways to procure a house: one can purchase an existing house, buy a plot and build a house oneself (owner-builders) or purchase a new house from a developer.

Both owner-builders and housing developers operate by subcontracting most of the construction work to specialty trade contractors. Indeed, as much as $90 \%$ of the construction work is carried out by different trade contractors, while the main contractor tends to focus on management and coordination (Karim, Marosszeky \& Davis 2006). Generally, developers solicit bids from contractors for the construction of all the dwellings in a tract and award the contract to the lowest bidder. Moreover, the 'multi-layer chain subcontracting system', which is widely used in the construction industry, encourages improper work practices by subcontractors and involves long chains of command, thereby contributing to poor quality performance, communication and coordination (Tam, Shen \& Kong, 2011). Further complications arise because most subcontractors involved in housing construction are small. In Spain, for example, 94\% of construction firms have fewer than 20 employees (Asociación de empresas constructoras de ámbito nacional (SEOPAN) 2009). These problems, combined with the fact that it is the main contractor who is ultimately responsible for delivering quality at a competitive cost, mean that some defects are not solved in the construction and handover stages (Karim, Marosszeky \& Davis 2006). As a result, these defects remain in the post-handover period, when the building is supposed to be completely finished.

Compounding the matter, end clients do not become involved in the construction process until it is nearly over. In fact, clients play a negligible role in defining both the functional requirements and the quality standards of new houses. Roy and Cochrane (1999) stressed the need for a customer-focused approach due to the considerable effort involved in after-sales rectification of newly built homes. Indeed, as a result of this situation, the last decade has seen a constant clamour from both clients and government for improvements in the quality of the finished product delivered by the construction industry (Sommerville \& McCosh 2006).

Accordingly, standards for the performance of new housing have become stricter. In Spain, the Ley de Ordenación de la Edificación (LOE) (Jefatura del Estado 1999), enacted in 2000 to regulate the construction process, established the rights and responsibilities of all stakeholders, as well as the compulsory warranties to assure that buildings meet basic requirements with regard to functionality (utilization, telecommunications, audiovisual and information accessibility and access), general safety and structure, fire-proofing, and use and habitability (hygiene, health, environmental and noise protection, energy savings, thermal insulation and other functional aspects). The aim of these standards is to ensure that customer/client 
requirements are set out and addressed from the start of the project, including clear guidelines for what constitutes an acceptable benchmark for each building element upon completion. This is relatively easy to achieve in the commercial sphere, where a single client engages a range of construction professionals to establish and refine project requirements and supervise the project, ensuring that the end product conforms to the agreed parameters. However, it is not so easy in the case of houses built by developers, in which clients are not involved in the construction process until the end and each client has a different set of perceptions and expectations. The quality dissonance seen in the case of buyers of new homes depends on the level and range of defects found. This dissonance may well arise from the fact that the client (homebuyer) thinks that he or she is setting the quality requirements when in fact he or she is merely a purchaser of what might be considered a second-hand set of requirements (Sommerville \& McCosh 2006). To date, the task of setting requirements for residential buildings built by developers has fallen to the builder or contractor.

\section{HOUSING DEFECTS}

Many researchers have analysed construction defects and their causes during the design and construction stages, but the defects that remain once the main contractor has delivered the building have received scant attention. In fact, the expected and perceived levels of product quality vary with the different procurement approaches (Georgiou, Love \& Smith 1999). Owner-builders determine their needs and control the whole construction process themselves. Therefore, they perceive few defects once the house has been delivered. In contrast, most clients do not see the dwellings built by developers until after the contractor has delivered them to the developer. As a result, client expectations may differ from what they actually receive. Moreover, if a product does not meet the desired quality level, people may perceive the discrepancy as a defect. In fact, the perception of quality and what constitutes defective work may vary between the client, the developer and the contractor (Georgiou, Love \& Smith 1999).

Defects are mainly reduced and/or eliminated prior to handover (when most of the controls and inspections take place). When this occurs, the defects are not visible to the client and are considered to have been absorbed by the main contractor or trade contractors. However, if the trade contractors fail to finish the work, or if defective work is detected once they have left the site, it can be difficult for the main contractor to bring them back to rectify the problem, since most of them will already have moved on to new projects (Love 2002). Consequently, some work will need to be undertaken in the post-handover stage, when the client has already moved into the dwelling. This type of defective and incomplete work is considered to be a visible defect, since it is brought to the client's attention. Such situations can affect a company's reputation.

\section{RESEARCH METHODOLOGY}

This paper aims to analyse the quality perceived by end users in the post-handover stage and to determine whether there is a significant difference between the two main residential building types built by developers, flats and detached houses. It also aims to 
identify the influence of different building parameters on the number of defects detected in each building type and to determine the most common building elements and areas where housing defects are found in the post-handover stage.

The first step was to identify the data to be tracked. Data were classified into building characteristics and defect characteristics. Building characteristics included building type, gross floor area of the dwelling, construction cost, number of floors in the building, number of dwellings per development, distance from the contractor's headquarters to the site and number of rooms per dwelling. Defect characteristics included information about where in the building the defect was found (e.g. bathroom, terrace, etc.) and the affected building element (e.g. internal wall, window, etc.).

The second step was to collect, analyse and evaluate data from client complaint forms completed following the handover of 95 dwellings. Data were only collected on defects in new flats and detached houses - both common building types in Spain - in order to ensure that the data were representative of the defects typically found in the country. These data were used to:

- Determine the number of defects and whether the building type (flat or detached house) influenced the defects detected by the client.

- Analyse the influence of a dwelling's building characteristics on the detected defects and compare the findings for each building type.

- Identify the specific problem areas in the dwelling where defects were most likely to occur and compare the findings for each building type.

- Identify the specific element of the building where defects were most likely to be detected by end users and compare the findings for each building type.

- Determine which areas and elements require greatest supervision to satisfy end users.

The data collected were analysed using Minitab (version 16) and the Statistical Package for the Social Sciences (SPSS) for Windows (version 17.00). Minitab was used to determine the distribution type of the construction defects for each building type by performing the Anderson-Darling test, as well as to determine the normal probability plot correlation coefficient (r). The correlation coefficient (r) was compared with the critical values proposed by Filliben (1975). Minitab was also used to determine the mean, standard deviation, standard error mean and confidence interval at $95 \%$.

SPSS was used to identify where any differences between samples might lie by means of a t-test. In addition, to test variables' associations with the different characteristics of each building type, Pearson's parametric correlation was computed. This approach made it possible to identify those variables with significant correlations at the $95 \%$ and 99\% confidence intervals. Finally, a chi-square test was performed to test the dependence between the building type and the affected element or area.

\section{DATA ANALYSIS}

A total of 95 flats and detached houses were selected. Table 1 shows the main characteristics of the analysed buildings. 


\begin{tabular}{ccccc}
\hline Building type & $\begin{array}{c}\text { Number of } \\
\text { dwellings }\end{array}$ & $\begin{array}{c}\text { Average } \\
\text { construction cost }\end{array}$ & $\begin{array}{c}\text { Average } \\
\text { gross floor } \\
\text { area }\end{array}$ & $\begin{array}{c}\text { Average } \\
\text { number of } \\
\text { floors }\end{array}$ \\
\hline Detached house & 46 & $€ 1,320 / \mathrm{m}^{2}$ & $137 \mathrm{~m}^{2}$ & $\mathrm{GF}+1$ \\
\hline Flat & 49 & $€ 1,068 / \mathrm{m}^{2}$ & $83 \mathrm{~m}^{2}$ & $\mathrm{GF}+5$ \\
\hline
\end{tabular}

Table 1 Building characteristics

Data were taken directly from 'client complaint forms' collected in the field, which contained all the necessary information in the description of the defect.

To further reduce variability and improve data quality, buildings for which proper defect records were not kept or for which no proper descriptions of the defects were given were eliminated.

\subsection{Building types}

The Anderson-Darling test was carried out to determine the type of distribution for each building type.

\begin{tabular}{lllllllll}
\hline $\begin{array}{l}\text { Building } \\
\text { type }\end{array}$ & No. & Mean & $\begin{array}{l}\text { Standard } \\
\text { deviation }\end{array}$ & $\begin{array}{l}\text { Standard } \\
\text { error } \\
\text { mean }\end{array}$ & Distribution & $\begin{array}{l}\text { p-value } \\
\text { (Anderson- } \\
\text { Darling } \\
\text { test) }\end{array}$ & $\begin{array}{l}\text { Normal } \\
\text { probability } \\
\text { plot } \\
\text { correlation } \\
\text { coefficient (r) }\end{array}$ & $\begin{array}{l}\mathbf{9 5 \%} \\
\text { CI }\end{array}$ \\
\hline $\begin{array}{l}\text { Detached } \\
\text { houses }\end{array}$ & 46 & 21.000 & 7.80313 & 1.15051 & Normal & 0.375 & 0.9793 & $18.68 ;$ \\
Flats & 49 & 28.306 & 16.69232 & 2.38462 & Normal & 0.103 & 0.9795 & 23.32 \\
\end{tabular}

Table 2 Anderson-Darling test to compare the two samples (flat vs detached houses)

The p-value of this test for a normal distribution was not less than or equal to 0.05 for either building type (Table 2). Moreover, the normal probability plot correlation coefficient (r) was greater than the $5 \%$ critical value in both cases $(0.9793$ for detached houses and 0.9795 for flats). It can thus be assumed that the defects in both groups have a normal distribution with $95 \%$ confidence. Specifically, the number of defects detected in detached houses ranged from 18.68 to 23.32 , and the number of defects detected in flats from 23.51 to 33.10 , with a $95 \%$ confidence interval.

To determine whether the number of defects varied between detached houses and flats, a t-test was performed (Table 3).

Levene's test for homogeneity of variances was violated for detached houses and flats ( $>>0.05)$, indicating that the population variances for each group were different.

At the $95 \%$ confidence level, the number of defects varied significantly by residential building type. It was thus concluded that the number of defects varied significantly 
between the two samples and that detached houses and flats could not be reclassified into a single category.

\begin{tabular}{|c|c|c|c|c|c|c|c|c|c|}
\hline & \multicolumn{2}{|c|}{$\begin{array}{l}\text { Levene's test } \\
\text { for equality } \\
\text { of variances }\end{array}$} & \multicolumn{2}{|c|}{$\begin{array}{l}\text { t-Test for } \\
\text { equality of } \\
\text { means }\end{array}$} & \multirow[t]{2}{*}{$\begin{array}{c}\text { Sig } \\
(2- \\
\text { tailed) }\end{array}$} & \multirow[t]{2}{*}{$\begin{array}{l}\text { Mean } \\
\text { dif. }\end{array}$} & \multirow[t]{2}{*}{$\begin{array}{l}\text { Stand. } \\
\text { error } \\
\text { dif. }\end{array}$} & \multicolumn{2}{|c|}{$\begin{array}{l}95 \% \text { CI of } \\
\text { difference }\end{array}$} \\
\hline & $\mathbf{F}$ & sig & $t$ & df & & & & Lower & Upper \\
\hline $\begin{array}{l}\text { Equal } \\
\text { variances } \\
\text { assumed }\end{array}$ & 30.963 & 0.000 & -2.704 & 93 & 0.008 & -7.30612 & 2.70241 & -12.67256 & -1.93968 \\
\hline $\begin{array}{l}\text { Equal } \\
\text { variances } \\
\text { not } \\
\text { assumed }\end{array}$ & & & -2.759 & 68.962 & 0.007 & -7.30612 & 2.64765 & -12.58810 & -2.02415 \\
\hline
\end{tabular}

Table $3 \mathrm{t}$-Test to compare the two samples (flat vs detached houses)

\subsection{Influence of building characteristics}

To test whether there was a significant relationship between defects and different construction parameters (gross floor area of the dwelling, construction cost, number of dwellings per development, etc.), a Pearson's (r) correlation was computed. This analysis was used for both detached houses (Table 4) and flats (Table 5).

It should be noted that a positive Pearson's ( $r$ ) correlation value indicates that when a variable increases, so does the related variable. In contrast, a negative Pearson's (r) correlation value indicates that when a variable increases, the related variable decreases. The r-value was used to calculate the $r^{2}$ value, which indicates the extent to which one variable can be predicted by changes in another (Love 2002).

According to the results (Table 4), the number of defects in detached houses was significantly related to all other variables.

\begin{tabular}{|c|c|c|c|c|c|c|c|}
\hline & $\begin{array}{c}\mathrm{N}^{0} \text { of } \\
\text { defects }\end{array}$ & $\begin{array}{l}\text { Gross } \\
\text { floor } \\
\text { area }\end{array}$ & $\begin{array}{c}\text { Constr. } \\
\text { cost }\end{array}$ & $\begin{array}{c}\mathrm{N}^{\mathbf{0}} \text { of } \\
\text { dwellings }\end{array}$ & Distance & $\begin{array}{l}N^{0} \text { of } \\
\text { floors }\end{array}$ & $\begin{array}{c}\mathrm{N}^{\circ} \text { of } \\
\text { room } \\
\mathrm{S}\end{array}$ \\
\hline Defects & 1 & - & - & & & & \\
\hline Gross floor area & $0.676 * *$ & 1 & - & & & & \\
\hline Construction cost & $-0.659 * *$ & $-0.973 * *$ & 1 & & & & \\
\hline $\mathrm{N}^{\mathrm{o}}$ of dwellings & $0.409 * *$ & $0.610 * *$ & -0.409 & 1 & & & \\
\hline Distance & $-0.676^{* *}$ & -1.000 & $0.973 * *$ & -0.610 & 1 & & \\
\hline Number of floors & $0.676^{* *}$ & $1.000 * *$ & $-0.973 * *$ & $0.610 * *$ & -1.000 & 1 & \\
\hline Number of rooms & $0.337 *$ & 0.492 & $-0.680 * *$ & $-0.390 * *$ & -0.492 & $\begin{array}{l}0.49 \\
2 * *\end{array}$ & 1 \\
\hline
\end{tabular}

** Correlation is significant at 0.01 level (2-tailed)

* Correlation is significant at 0.05 level (2-tailed)

Table 4 Correlation matrix for defects and characteristics of detached houses 
For detached houses, the correlation coefficients revealed that the number of defects was significantly related to the gross floor area $(r=+0.676, n=46, p<0.01$, two tails and $\left.r^{2}=0.4570(45.70 \%)\right)$. Specifically, the larger the gross floor area, the more defects were detected. Some $45.70 \%$ of the variance in defects can be attributed to changes in the gross floor area.

Similarly, the number of defects was also significantly related to the distance between the contractor's headquarters and the site $(\mathrm{r}=-0.676, \mathrm{n}=46, \mathrm{p}<0.01$, two tails and $\left.r^{2}=0.4570(45.70 \%)\right)$. In this case, too, the longer the distance from the contractor's headquarters to the site, the fewer the defects. While this is a surprising finding, a detailed examination of the project data revealed that buildings built near the contractor's headquarters were built by the firm's own employees, whereas the work was subcontracted for buildings built far from a contractor's headquarters. As Atkinson (2002) has concluded, there is a strong correlation between defects and management practice. Although the coordination of a large number of subcontractors is a source of defects during the construction process (Karim, Marosszeky \& Davis 2006), most of the defects due to poor subcontractor coordination are detected during the construction and handover stages, when a large number of quality controls are carried out. In general, the defective and incomplete work remaining in the posthandover stage is specialty work, such as painting, cleaning, or the installation of mechanical and electrical appliances, carried out by subcontractors that have already left the site when the quality controls take place.

In fact, the defects detected in each stage of a building's lifecycle (construction, handover, post-handover and maintenance (Chong \& Low 2005)) are different, just as the perception of quality and what constitutes defective work varies between the client, the developer and the contractor (Georgiou, Love \& Smith 1999).

The number of defects was also significantly related to construction cost $(\mathrm{r}=-0.659$, $\mathrm{n}=46, \mathrm{p}<0.01$, two tails and $\mathrm{r}^{2}=0.4343(43.43 \%)$ ). As expected, the higher the construction cost, the fewer the defects detected. This is not entirely surprising, as it is also true that the higher the construction cost, the more quality inspections and controls are included in the construction process and the better quality the materials and finishes used, which results in a higher quality final product (Georgiou, Love \& Smith 1999). However, cost is not always directly related to quality or, more specifically, to the quality perceived by clients. According to Georgiou (1995), some building elements vary in quality, but not necessarily in terms of how they work. For example, the porosity and water absorption of floor tiles might affect a building's lifespan even though the tiles function satisfactorily. Indeed, clients may not even notice such latent defects upon entering the building as most building defects do not become visible until two years after occupancy (Chong, Low 2006).

The number of defects was also significantly related to the number of dwellings in the development $\left(r=-0.409, n=46, p<0.01\right.$, two tails and $\left.r^{2}=0.1673(16.73 \%)\right)$ and to the number of rooms $\left(\mathrm{r}=0.337, \mathrm{n}=46, \mathrm{p}<0.05\right.$, two tails and $\mathrm{r}^{2}=0.1137(11.33 \%)$ ). However, $\mathrm{r}^{2}$ was low, indicating that only $16.73 \%$ of the variance in defects could be predicted by changes in the development. Likewise, only $11.37 \%$ of the variance in defects could be predicted by changes in the number of rooms. 
For flats, the floor was also considered. For this building type, the correlation data revealed a significant relationship between the number of defects and all variables except the floor (Table 5).

\begin{tabular}{|c|c|c|c|c|c|c|c|c|}
\hline & $\begin{array}{l}N^{0} \mathbf{r} \text { of } \\
\text { defect } \\
\text { s }\end{array}$ & GFA & $\begin{array}{l}\text { Constr. } \\
\text { cost }\end{array}$ & $\begin{array}{l}\mathrm{N}^{\mathbf{0}} \text { of } \\
\text { dwellings }\end{array}$ & Distance & $\begin{array}{l}N^{0} \text { of } \\
\text { rooms }\end{array}$ & $\begin{array}{l}N^{0} \text { of } \\
\text { floors }\end{array}$ & Floor \\
\hline Defects & 1 & - & - & & & & & \\
\hline GFA & $-0.611 * *$ & 1 & - & & & & & \\
\hline Constr. cost & $-0.601 * *$ & $-0.920 * *$ & 1 & & & & & \\
\hline $\mathrm{N}^{\circ}$ of dwellings & $-0.526 * *$ & $0.684 *$ & $-0.571 * *$ & 1 & & & & \\
\hline Distance & $-0.328^{* *}$ & $0.742 * *$ & -0.477 & $0.289^{*}$ & 1 & & & \\
\hline $\mathrm{N}^{\circ}$ of rooms & $-0.445^{* *}$ & $0.498 * *$ & -0.769 & $0.471 * *$ & -0.193 & & & \\
\hline $\mathrm{N}^{\circ}$ of floors & $0.441^{* *}$ & -0.588 & $0.858 * *$ & $-0.283^{*}$ & -0.009 & $.936 * *$ & 1 & \\
\hline Floor & -0.083 & $0.286^{*}$ & -0.206 & 0.105 & $0.357 *$ & .030 & -0.05 & 1 \\
\hline
\end{tabular}

Table 5 Correlation matrix for defects and characteristics of flats

The data showed that the number of defects was significantly related to the number of floors in the building ( $r=-0.441, n=49, \mathrm{p}<0.01$, two tails and $\mathrm{r}^{2}=0.1945(19.45 \%)$ ). In this case, the taller the building, the smaller the dwellings $(r=-0.588, n=49, p<0.01)$.

In a flat development, many more dwellings are built with the same characteristics. (In this study, there was an average of 112 flats per development compared to 28 detached houses per development). The taller the building, the more defects were detected. While this is a surprising finding and it is often difficult to identify the causes, Atkinson (1999) noted that most defects are related to the people who carry out the construction. More specifically, lack of worker motivation is one of the main causes of building defects (Josephson \& Hammarlund 1999). Given that work on flats is more repetitive than work on detached houses, workers might pay less attention to what they are doing out of boredom or carelessness. A detailed examination of the project data showed that flats were subject to a tighter schedule than detached houses and that work on them thus had to be rushed to meet the targets. The fact that workers were working under higher pressure led to more defects in the finished work. The implication of this is that the occurrence of defects cannot be treated in isolation and that any analysis of cause must treat the whole project as a system (Atkinson 1999).

The number of defects was also significantly related to construction cost $(\mathrm{r}=-0.601$, $\mathrm{n}=49, \mathrm{p}<0.01$, two tails and $\mathrm{r}^{2}=0.3612(36.12 \%)$ ). As with detached houses, the higher the construction cost, the fewer the defects detected.

As with detached houses, here too the number of defects was significantly related to the distance between the contractor's headquarters and the site $(r=-0.328, n=49$, $p<0.05$, two tails and $r^{2}=0.1076(10.76 \%)$ ). However, only $10.76 \%$ of the variance in defects could be predicted by changes in this distance.

The correlation analysis for flats did not show any significant relationship between the number of defects and the dwellings' floor areas. In fact, in contrast to detached houses, the larger the gross floor area of a flat, the fewer the defects detected. This is 
related to the types of defects clients detect. In flats, many defects are detected in general areas such as the entrance hall, façade, etc. They thus do not depend on the dwelling's gross floor area.

Moreover, the analysis does not consider the magnitude of the defects. For example, a levelness defect caused by shoddy workmanship is counted as a single defect regardless of the magnitude of the affected element.

\subsection{Defects by area}

A contingency table (Table 6) and chi-square hypothesis test of independence (Table 7) were used to test the independence of the two samples. This test assesses whether paired observations on two variables, expressed in a contingency table, are independent of each other.

\begin{tabular}{|c|c|c|c|c|c|c|c|c|}
\hline \multirow[t]{3}{*}{ Zone } & \multicolumn{6}{|c|}{ Building type } & \multicolumn{2}{|c|}{ Total } \\
\hline & & Detached & ouses & & Flats & & & \\
\hline & $\begin{array}{c}\mathrm{N}^{\mathrm{o}} \text { of } \\
\text { defects }\end{array}$ & $\begin{array}{c}\% \text { of } \\
\text { defects in } \\
\text { the same } \\
\text { area }\end{array}$ & $\begin{array}{c}\% \text { of defects } \\
\text { in the same } \\
\text { building } \\
\text { type }\end{array}$ & $\begin{array}{l}\mathrm{N}^{\circ} \text { of } \\
\text { defects }\end{array}$ & $\begin{array}{c}\% \text { of } \\
\text { defects in } \\
\text { the same } \\
\text { area }\end{array}$ & $\begin{array}{c}\% \text { of defects } \\
\text { in the same } \\
\text { building } \\
\text { type }\end{array}$ & $\begin{array}{c}\mathrm{N}^{\mathrm{o}} \text { of } \\
\text { defects }\end{array}$ & $\begin{array}{c}\% \text { of } \\
\text { defects in } \\
\text { the same } \\
\text { area }\end{array}$ \\
\hline Balcony & 63 & 38.41 & 6.52 & 101 & 61.59 & 7.28 & 164 & 6.97 \\
\hline Bathroom & 165 & 41.67 & 17.08 & 231 & 58.33 & 16.65 & 396 & 16.83 \\
\hline Corridor & 5 & 31.25 & 0.52 & 11 & 68.75 & 0.79 & 16 & 0.68 \\
\hline $\begin{array}{l}\text { Entrance } \\
\text { hall }\end{array}$ & 0 & 0.00 & 0.00 & 47 & 100.00 & 3.39 & 47 & 2.00 \\
\hline Exterior & 34 & 100.00 & 3.52 & 0 & 0.00 & 0.00 & 34 & 1.44 \\
\hline Garage & 84 & 97.67 & 8.70 & 2 & 2.33 & 0.14 & 86 & 3.65 \\
\hline General & 50 & 33.33 & 5.18 & 100 & 66.67 & 7.21 & 150 & 6.37 \\
\hline Hall & 69 & 40.83 & 7.14 & 100 & 59.17 & 7.21 & 169 & 7.18 \\
\hline Kitchen & 96 & 27.27 & 9.94 & 256 & 72.73 & 18.46 & 352 & 14.96 \\
\hline Lounge & 85 & 34.00 & 8.80 & 165 & 66.00 & 11.90 & 250 & 10.62 \\
\hline Porch & 35 & 100.00 & 3.62 & 0 & 0.00 & 0.00 & 35 & 1.49 \\
\hline Room & 154 & 31.49 & 15.94 & 335 & 68.51 & 24.15 & 489 & 20.78 \\
\hline Stairs & 69 & 94.52 & 7.14 & 4 & 5.48 & 0.29 & 73 & 3.10 \\
\hline Suite & 7 & 31.82 & 0.72 & 15 & 68.18 & 1.08 & 22 & 0.93 \\
\hline Terrace & 48 & 81.36 & 4.97 & 11 & 18.64 & 0.79 & 59 & 2.51 \\
\hline Yard & 2 & 18.18 & 0.21 & 9 & 81.82 & 0.65 & 11 & 0.47 \\
\hline 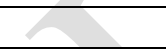 & 966 & 41.05 & 100.00 & 1,387 & 58.95 & 100.00 & 2,353 & 100.00 \\
\hline
\end{tabular}

Table 6 Contingency table between area and building type

\begin{tabular}{llll}
\hline & Value & df & $\begin{array}{l}\text { Asymp. sig } \\
\text { (2-tailed) }\end{array}$ \\
\hline Pearson chi-square & $430.827^{\text {a }}$ & 15 & 0.000 \\
Likelihood ratio & 503.405 & 15 & 0.000 \\
No. of valid cases & 2,353 & & \\
\hline
\end{tabular}

a. One cell (3.1\%) had an expected count of less than 5. The minimum expected count was 4.52 .

Table 7 Chi-square hypothesis test of independence 
The fact that the Pearson chi-square value under 'Asymp. Sig' is 0.000 and less than 0.05 indicates that the area of the building where the defect was detected and the building type were dependent. In general, this means that it is worth interpreting the cells in the contingency table. Although one cell (yard for detached houses) had an expected count of less than 5 , the minimum expected count was 4.52 , which is a valid result.

Table 6 shows that many defects were detected in wet areas (16.83\% in bathrooms, $14.96 \%$ in kitchens). Although wet areas do not usually account for more than $10 \%$ of a building's gross floor area, defects resulting from defective construction in wet areas account for a large share of the rework costs (Chew 2005).

The results also show that most of the defects $(63.19 \%)$ were detected inside the dwelling (16.83\% in bathrooms, $14.96 \%$ in kitchens, $10.62 \%$ in lounges and $20.78 \%$ in bedrooms). Defects on the outside of the building, such as those detected in the exterior, porch or terrace, were only considered in detached houses and made up only a small share of the total.

Balcony defects were more frequent in flats $(61.59 \%)$ than in detached houses (38.41\%), although they still accounted for only a small percentage of the total (7.28\%). This is because detached houses have fewer and smaller balconies than flats.

Defects in entrance halls were only detected in flats, as this area does not exist in detached houses.

Although the garage was an important area in both detached houses and flats, $97.67 \%$ of defects detected in garages were detected in detached houses. This does not mean that there were no defects in the garages of flats, but that flat buyers did not detect defects in areas beyond the habitable dwelling itself. Moreover, most of the defects in garages were associated with damp floors, a defect that is not detected upon first entering the house but rather is latent.

Most of the defects detected in kitchens were detected in flats $(72.73 \%)$, and $18.46 \%$ of all defects detected in flats were detected in this area. Most kitchen defects were related to furnishings and appliances. Thus, broken and malfunctioning washing machines, boilers, refrigerators, etc. were also included in this category. According to Porteous (1992) and Georgiou, Love and Smith (1999), clients' tolerance of defects and perception of quality may differ from that of contractors and developers. Generally, quality controls at handover do not include furnishings and appliances, so these types of defects are not detected until the dwelling is first occupied. A detailed examination of the project data also showed that the appliances in detached houses were higher quality. This increases clients' comfort upon occupying a dwelling and reduces the number of defects detected.

Stairs and terraces are common areas in flats, whereas with detached houses they are part of each dwelling. The fact that a higher percentage of defects were detected in stairs $(94.52 \%)$ and terraces $(81.36 \%)$ in detached houses than in flats indicates that the justification for the number of defects detected in the garage area can be extrapolated 
to other common areas such as stairs and terraces, as well. Again, this analysis does not mean that there are no defects in the common areas of flats, but rather that the end users of flats do not tend to detect defects in areas beyond the habitable dwelling itself.

\subsection{Defects by element}

A contingency table (Table 8) and chi-square hypothesis test of independence (Table 9) were used to test the independence of the elements in which defects were detected in each building type.

\begin{tabular}{|c|c|c|c|c|c|c|c|c|}
\hline \multirow[t]{3}{*}{ Element } & \multicolumn{6}{|c|}{ Building type } & \multicolumn{2}{|c|}{ Total } \\
\hline & \multicolumn{3}{|c|}{ Detached houses } & \multicolumn{3}{|c|}{ Flats } & \multirow[b]{2}{*}{$\begin{array}{c}\mathrm{N}^{\mathrm{o}} \text { of } \\
\text { defects }\end{array}$} & \multirow[b]{2}{*}{$\begin{array}{l}\% \text { of } \\
\text { defects } \\
\text { in the } \\
\text { same } \\
\text { area }\end{array}$} \\
\hline & $\begin{array}{c}\mathrm{N}^{\mathrm{o}} \text { of } \\
\text { defects }\end{array}$ & $\begin{array}{c}\% \text { of } \\
\text { defects } \\
\text { in the } \\
\text { same } \\
\text { area }\end{array}$ & $\begin{array}{c}\% \text { of } \\
\text { defects in } \\
\text { the same } \\
\text { building } \\
\text { type }\end{array}$ & $\begin{array}{c}\mathrm{N}^{\mathbf{o}} \text { of } \\
\text { defects }\end{array}$ & $\begin{array}{c}\% \text { of } \\
\text { defects } \\
\text { in the } \\
\text { same } \\
\text { area }\end{array}$ & $\begin{array}{c}\% \text { of } \\
\text { defects in } \\
\text { the same } \\
\text { building } \\
\text { type }\end{array}$ & & \\
\hline Ceiling & 39 & 45.88 & 4.04 & 46 & 54.12 & 3.32 & 85 & 3.61 \\
\hline Door & 187 & 54.52 & 19.36 & 156 & 45.48 & 11.25 & 343 & 14.58 \\
\hline $\begin{array}{l}\text { External } \\
\text { wall }\end{array}$ & 91 & 50.28 & 9.42 & 90 & 49.72 & 6.49 & 181 & 7.69 \\
\hline Floor & 49 & 22.17 & 5.07 & 172 & 77.83 & 12.40 & 221 & 9.39 \\
\hline Furniture & 38 & 23.60 & 3.93 & 123 & 76.40 & 8.87 & 161 & 6.84 \\
\hline General & 26 & 22.03 & 2.69 & 92 & 77.97 & 6.63 & 118 & 5.01 \\
\hline $\begin{array}{l}\text { Internal } \\
\text { wall }\end{array}$ & 117 & 35.56 & 12.11 & 212 & 64.44 & 15.28 & 329 & 13.98 \\
\hline Item & 179 & 41.53 & 18.53 & 252 & 58.47 & 18.17 & 431 & 18.32 \\
\hline M\&E & 33 & 40.24 & 3.42 & 49 & 59.76 & 3.53 & 82 & 3.48 \\
\hline $\begin{array}{l}\text { Plumbing } \\
\&\end{array}$ & 8 & 25.81 & 0.83 & 23 & 74.19 & 1.66 & 31 & \\
\hline sanitary & & & & & & & & 1.32 \\
\hline Roof & 0 & 0.00 & 0.00 & 18 & 100.00 & 1.30 & 18 & 0.76 \\
\hline Stairs & 13 & 92.86 & 1.35 & 1 & 7.14 & 0.07 & 14 & 0.59 \\
\hline \multirow[t]{2}{*}{ Window } & 185 & 54.73 & 19.15 & 153 & 45.27 & 11.03 & 338 & 14.36 \\
\hline & 966 & 41.05 & 100.00 & 1,387 & 58.95 & 100.00 & 2,353 & 100.00 \\
\hline
\end{tabular}

Table 8 Contingency table between element and building type

\begin{tabular}{llcc}
\hline & Value & df & $\begin{array}{l}\text { Asymp. sig. } \\
\text { (2-tailed) }\end{array}$ \\
\hline Pearson chi-square & $166.115^{\text {a }}$ & 13 & 0.000 \\
Likelihood ratio & 179.082 & 13 & 0.000 \\
No. of valid cases & 2,353 & & \\
\hline
\end{tabular}

Table 9 Chi-square hypothesis test of independence

In this case, the Pearson chi-square value was also less than 0.05 . Therefore, it was possible to reject the null hypothesis of independence and claim that a relationship exists between the element and building type. 
Table 8 shows that the breakdown of defects by element differed depending on the building type. Table 8 also shows that $42.92 \%$ of the defects were detected in partition and closure elements (13.98\% in internal walls, $14.58 \%$ in doors and $14.36 \%$ in windows). According to Sommerville and McCosh (2006), defects detected by end users in the post-handover stage can be divided into three categories: technical defects, omissions and aesthetic defects. Technical defects refer to when the workmanship, material or design of a building element hinders its ability to function properly; omissions refer to parts of the dwelling that are simply left out; and aesthetic defects refer to defects adversely affecting the appearance of a building element (Georgiou, Love \& Smith 1999). Based on an analysis of the results, most of the internal wall defects were omissions or technical defects. Omissions in walls mainly refer to painting, whereas technical defects refer to cracks near windows and doors (Olubodun and Mole 1999).

Omissions also include items such as baseboards, sockets or tiles that have been omitted. These defects are also quite commonly detected in the post-handover stage, as seen in this analysis (18.32\%). Defects in doors and windows were mainly technical defects, such as malfunctioning locks or blinds or doors that brushed the floor.

It is also significant that mechanical and electrical (3.48\%) and plumbing and sanitary $(1.32 \%)$ defects were significantly less frequent than defects in other elements in both flats and detached houses. Mechanical and electrical facilities must pass a test upon installation and prior to use (Georgiou, Love \& Smith 1999), and plumbing and sanitary facilities are generally so simple and straightforward activities in a dwelling that workers are less likely to make mistakes in their installation (Olubodun \& Mole 1999).

It is likewise worth noting that floor defects were more frequent in flats $(77.83 \%)$ than detached houses $(22.17 \%)$, and $12.40 \%$ of all defects in flats fell into this category. Most of the floor defects detected by clients were associated with the omission of elements such as polish or aesthetic defects such as broken, stained or hollow tiles or chips due to a lack of protection during the construction process or inferior material quality. The fact that flats were subject to a tighter schedule than detached houses may have led workers to scrimp on the time required to protect elements or parts of the building when executing other construction processes. However, material defects take time to develop and usually appear during occupancy (Chong \& Low 2005).

Finally, it is significant that neither those managerial defects that are mainly solved during the construction and handover stages nor other defects due to age, such as broken panes, condensation or cracks in walls, were detected at this stage.

\section{CONCLUSIONS}

The research presented in this paper set out to analyse the factors that influence the quality perceived by clients in the first occupancy of a building. This analysis provides evidence that, even though clients are not aware of the quality of many non-visible structural elements or latent defects and only notice malfunctioning elements, 
omissions and aesthetic defects, many defects can still be found in newly built residential buildings, which are supposed to be complete. Such entirely avoidable defects are often detected by clients in the post-handover stage, damaging the image and reputation of the contractor and detracting from end-user satisfaction.

The analysis of 95 Spanish residential buildings showed that clients detect different defects in different types of residential buildings. Clients detect more defects in flats than in detached houses even though flats have a smaller gross floor area. This suggests that, the differences in contractors' and clients' perceptions of quality notwithstanding, contractors perceive end-user needs more accurately in detached houses than in flats. Building characteristics were investigated to determine whether a logical explanation existed. The lower quality of the materials used in flats compared to detached houses, the lack of motivation on the part of workers tasked with repetitive work, and the tighter schedule to which flats are subject, which forces workers to rush, might all be factors influencing the total number of defects detected by clients. However, other factors beyond the scope of this study may also contribute to the outcome, such as the levels of supervision of the workforce or workers' experience.

Despite the differences between flats and detached houses, in both cases developers meet their production volume goals by offering fixed products in terms of layout and quality specifications. The only client choices are the number of rooms, the gross floor area and certain furnishing in the kitchen and bathrooms. Moreover, clients (homebuyers) play a negligible role in defining the functional requirements and quality standards of the dwelling, because the quality standards are set and managed by the contractor. This is the main cause of the remaining defects detected by clients after the handover. Developers have been criticized for the excessive standardisation and poor quality of their products. If the industry is to become client-focused, the main drivers clearly need to be a new product strategy that offers more choice to clients, together with improvements in product quality and customer service. Cost will remain an important factor, but a more holistic approach needs to be taken so that the cost of defects in product and service quality can be taken into account.

These results can be used in practice, and the analysis can be built upon to further investigate this topical problem, which affects the residential building sector of the construction industry in many countries.

\section{REFERENCES}

Asociación de empresas constructoras de ámbito nacional (SEOPAN) 2009, Construcción Informe Regional.

Atkinson, A.R. 2002, "The pathology of building defects; a human error approach", Engineering, Construction and Architectural Management, vol. 9, no. 1, pp. 53-61.

Atkinson, A.R. 1999, "The role of human error in construction defects", Structural Survey, vol. 17, no. 4, pp. 231-236.

Chew, M.Y.L. 2005, "Defect analysis in wet areas of buildings", Construction and Building Materials, vol. 19, no. 3, pp. 165-173. 
Chong, W.K. \& Low, S.P. 2006, "Latent Building Defects: Causes and Design Strategies to Prevent Them", Journal of Performance of Constructed Facilities, vol. 20, no. 3, pp. 213-221.

Chong, W.K. \& Low, S.P. 2005, "Assessment of Defects at Construction and Occupancy Stages", Journal of Performance of Constructed Facilities, vol. 19, no. 4, pp. 283-289.

Farrington, J.J. 1987, A methodology to identify and categorize costs of quality deviations in design and construction, Graduate School of Clemson University.

Filliben, J.J. 1975, "The Probability Plot Correlation Coefficient Test for Normality", Technometrics, vol. 17, no. 1, pp. 111-117.

Georgiou, J., Love, P.E.D. \& Smith, J. 1999, "A comparison of defects in houses constructed by owners and registered builders in the Australian State of Victoria", Structural Survey, vol. 17, no. 3, pp. 160-169.

Hall, M. \& Tomkins, C. 2001, "A cost of quality analysis of a building project: towards a complete methodology for design and build", Construction Management \& Economics, vol. 19, no. 7, pp. 727-740.

Jefatura del Estado 1999, "LOE. Ley 38/1999, de 5 de noviembre, de Ordenación de la Edificación".

Josephson, P.E. 1998, "Defect and defect cost in construction: a study of seven building projects in Sweden", Department of Management of Construction and Facilities, Chalmers University of Technology, Gothenburg.

Josephson, P.E. \& Hammarlund, Y. 1999, "The causes and costs of defects in construction: A study of seven building projects", Automation in Construction, vol. 8, no. 6, pp. 681-687.

Josephson, P., Larsson, B. \& Li, H. 2002, "Illustrative Benchmarking Rework and Rework Costs in Swedish Construction Industry", Journal of Management in Engineering, vol. 18, no. 2, pp. 76-83.

Karim, K., Marosszeky, M. \& Davis, S. 2006, "Managing subcontractor supply chain for quality in construction", Engineering, Construction and Architectural Management, vol. 13, no. 1, pp. 27-42.

Love, P.E.D. 2002, "Influence of Project Type and Procurement Method on Rework Costs in Building Construction Projects", Journal of Construction Engineering and Management, vol. 128, no. 1, pp. 18-29.

Love, P.E.D. \& Sohal, A.S. 2003, "Capturing rework costs in projects", Managerial Auditing Journal, vol. 18, no. 4, pp. 329-339.

Olubodun, F. \& Mole, T. 1999, "Evaluation of defect influencing factors in public housing in the UK", Structural Survey, vol. 17, no. 3, pp. 170-178.

Porteous, W.A. 1992, "Classifying building failure by cause", Building Research \& Information, vol. 20, no. 6, pp. 350-356.

Roy, R. \& Cochrane, S.P. 1999, "Development of a customer focused strategy in speculative house building", Construction Management and Economics, vol. 17, no. 6, pp. 777-787.

Sommerville, J. \& McCosh, J. 2006, "Defects in new homes: an analysis of data on 1,696 new UK houses", Structural Survey, vol. 24, no. 1, pp. 6-21.

Tam, V.W.Y., Shen, L.Y. \& Kong, J.S.Y. 2011, "Impacts of multi-layer chain subcontracting on project management performance", International Journal of Project Management, vol. 29, no. 1, pp. 108-116. 